\title{
Basion-Cartilaginous Dens Interval: An Imaging Parameter for Craniovertebral Junction Assessment in Children
}

\author{
(D) A.K. Singh, (D) Zulton, (D) R. Tiwari, (D)X. Zhang, (D) Lu, LW.B. Altmeyer, and (1) B. Tantiwongkosi
}

\begin{abstract}
BACKGROUND AND PURPOSE: Widening of the basion-dens interval is an important sign of cranioverterbral junction injury. The current literature on basion-dens interval in children is sparse and based on bony measurements with variable values. Our goal was to establish the normal values of a recently described new imaging parameter, the basion-cartilaginous dens interval in children.
\end{abstract}

MATERIALS AND METHODS: Three hundred healthy pediatric patients (0-10 years of age) were selected retrospectively. These patients were divided into 3 different groups: A ( $0-3$ years), B (3-6 years), and C (6-10 years). The basion-cartilaginous dens interval was calculated on the sagittal MPR image of cervical spine CT in a soft-tissue window. The mean, SD, and the upper limit of normal (mean +2 SDs) of the 3 groups were calculated, and statistical tests were used to check for significant differences of the basion-cartilaginous dens interval among these 3 groups.

RESULTS: The upper limits of the basion-cartilaginous dens interval for the 3 groups were $5.34 \mathrm{~mm}$ in group A, $5.64 \mathrm{~mm}$ in group B, and 7.24 $\mathrm{mm}$ in group $\mathrm{C}$. There were statistically significant differences in the basion-cartilaginous dens interval values among the 3 groups. There was no statistically significant difference in basion-cartilaginous dens interval values between groups $A$ and $B$; however, values in group $C$ were significantly different from those in both $A$ and $B$. There was no statistically significant difference in the basion-cartilaginous dens interval values between males and females.

CONCLUSIONS: The basion-cartilaginous dens interval is a novel imaging parameter to assess cranioverterbral junction integrity in children, which includes the nonossified cartilage in the measurement.

ABBREVIATIONS: $B D I=$ basion-dens interval; $B C D I=$ basion-cartilaginous dens interval; $C V$ J $=$ craniovertebral junction

$\mathrm{T}$ he incidence of pediatric cervical spine injuries is between $1 \%$ and $2 \%$ of all patients with trauma. ${ }^{1,2}$ Upper cervical spine injuries are approximately twice as common as lower cervical spine injuries in children. ${ }^{3}$ Pure ligamentous injuries without fractures are more common in children younger than 9 years of age. ${ }^{4,5}$ Younger children are more susceptible to craniovertebral junction (CVJ) injuries due to a disproportionately large head size, laxity of the ligaments, and increased mobility at the craniovertebral junction. ${ }^{6,7}$ The basion-dens interval (BDI) is an important imaging marker for CVJ injuries; however, the literature on

Received May 25, 2017; accepted after revision August 3.

From the Department of Radiology, University of Texas Health Science Center San Antonio, San Antonio, Texas.

Paper previously presented at: Annual Meeting of American Society of Neuroradiology, April 22-27, 2017; Long Beach, California.

Please address correspondence to Achint K. Singh, MD, Department of Radiology, University of Texas Health Science Center San Antonio, 7703 Floyd Curl Dr, MC 7800, San Antonio, TX 78229; e-mail: singhak@uthscsa.edu

-- Indicates open access to non-subscribers at www.ajnr.org

http://dx.doi.org/10.3174/ajnr.A5400 pediatric BDI is limited. Moreover, BDI does not include the cartilaginous portion of the dens and is susceptible to variability in measurements. To address these limitations, a novel pediatric imaging parameter, the basion-cartilaginous dens interval (BCDI) has recently been introduced and described by Birchansky et al. ${ }^{8}$ As a substitute for BDI, we apply this new BCDI measurement in order to assess the normal values in children.

\section{MATERIALS AND METHODS}

This study was approved by our institutional review board for research. We retrospectively examined cervical spine CT scans in 300 pediatric patients (0-10 years of age) from 2013 to 2016. These patients were divided into 3 groups: $0-3$ years of age, 3-6 years of age, and 6-10 years of age. Seven radiologists ( 3 attending neuroradiologists and 4 second-year radiology residents) reviewed the CT scans in these patients. Each of the 3 attending neuroradiologists and 2 residents reviewed images in 50 different patients $(n=250)$, and each of the 2 other residents reviewed images in 25 different patients $(n=50)$. The patients were divided 


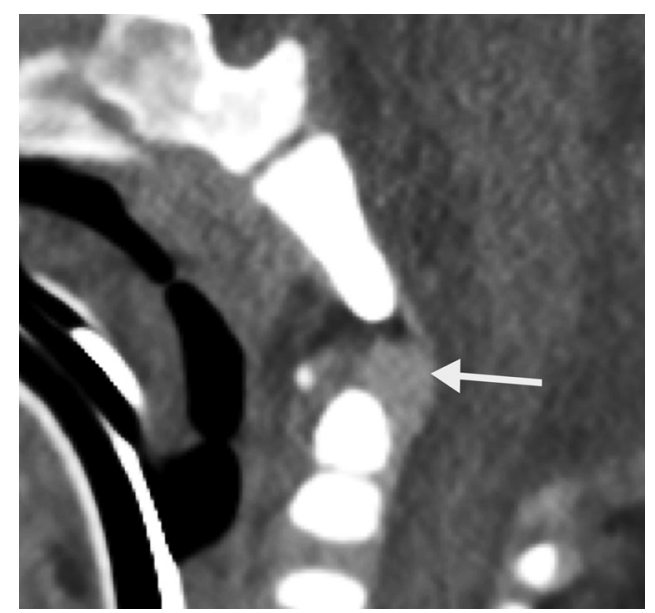

FIG 1. Sagittal CT cervical spine image (soft-tissue window) in a 6-month-old boy shows the soft-tissue cartilage around the dens (arrow).

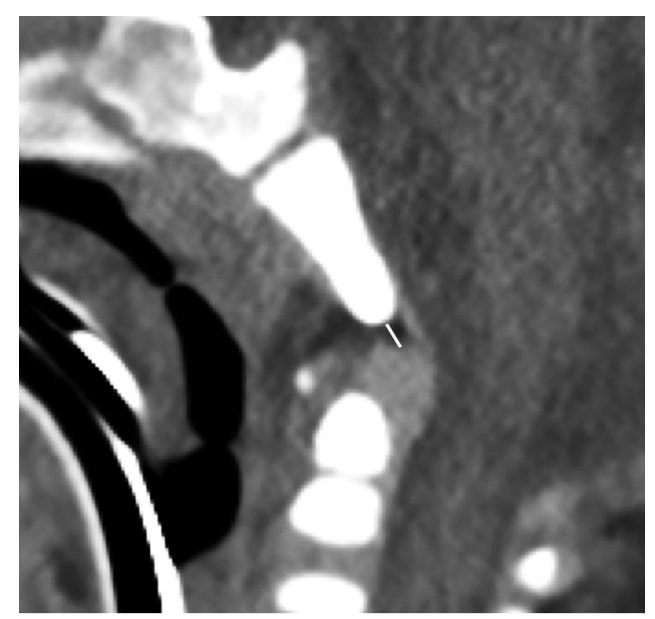

FIG 2. Sagittal CT cervical spine image (soft-tissue window) in a 6-month-old boy shows the technique for measuring BCDI as indicated by the line.

again among radiologists for a second review so that a different radiologist reviewed images in each patient. All radiologists received training on how to measure the BCDI. These measurements were obtained in sagittal reformatted images of the cervical spine in a soft-tissue window where cartilage can be easily seen around the dens (Fig 1). The minimum distance between the basion and tip of the dens was measured. If cartilage was seen, then the tip of the cartilage was used for measurement (Fig 2). If the dens was completely formed and the cartilage was not seen, then the tip of the bony dens was used for measurement. The BCDI measurement on each patient was obtained by 2 different readers, and an average of these 2 values was obtained for the data analysis.

Inclusion criteria for this study were normal cervical spine CT findings without any signs of craniovertebral junction injury based on imaging and clinical grounds. Exclusion criteria were any sign of craniovertebral junction injury, congenital anomalies of the CVJ, motion artifacts, and inadequate sagittal reformatted images in the soft-tissue window.

These patients were scanned on 2 similar machines (128-section Ingenuity; Philips Healthcare, Best, the Netherlands) with
BCDI values in 3 different groups

\begin{tabular}{lccc}
\hline Group & Mean & SD & $\begin{array}{c}\text { Upper Limit of } \\
\text { Normal (Mean +2 SDs) }\end{array}$ \\
\hline A (0-3 yr) & 3.87 & 0.73 & 5.34 \\
B (3-6 yr) & 3.80 & 0.92 & 5.64 \\
C (6-10 yr) & 5.31 & 0.96 & 7.24 \\
\hline
\end{tabular}

the same technical parameters: $128 \times 0.625-\mathrm{mm}$ collimation, 0.9-mm section thickness, 0.5-mm interval, with a pitch of 0.914 , $100 \mathrm{kV}$ (peak), and 70-100 mAs. Axial images were reconstructed at 1 and $3 \mathrm{~mm}$. Sagittal and coronal MPR images were reconstructed from axial 1-mm sections. Images were reviewed in the bone window (window level, $400 \mathrm{HU}$; window width, $2000 \mathrm{HU}$ ) and soft-tissue window (window level, $50 \mathrm{HU}$; window width, 450 $\mathrm{HU})$.

\section{Statistical Analysis}

All statistical analyses were performed on SAS statistical software, Version 9.4 (SAS Institute, Cary, North Carolina). All the patients were divided into 3 groups: group A ( $0-3$ years), group B (3-6 years), and group C (6-10 years). There were 172 males and 128 females. Descriptive statistical analysis was performed for the BCDI values in the 3 groups, and the mean, SD, and upper limit of normal values were obtained (Table). The upper limit of normal was defined as mean +2 SDs. The 1-way ANOVA test was performed to check the statistically significant difference in BCDI values among the 3 groups followed by a post hoc statistical test (Tukey) to check which group differed from the other groups. The Student $t$ test was performed to check the statistically significant difference in BCDI values between males and females. Interobserver agreement for the BCDI values was checked by using an intraclass correlation test. Descriptive analysis was also performed regarding the appearance and fusion of the os terminale, and the mean and SD were calculated. A $P$-value of .05 was considered significant.

\section{RESULTS}

The results for the BCDI values are summarized in the Table. There were statistically significant differences in the BCDI values among the 3 groups as calculated by 1-way ANOVA ( $P$ value $<$ $.001)$. The post hoc statistical tests were performed to compare which group differed from another. There was no statistically significant difference in BCDI values between groups A and B; however, values in group $C$ were significantly different from those in both A and B. There were 172 males and 128 females. There was no statistically significant difference in the BCDI values between males and females ( $t$ test, $P$ value $>.05$ ). The interobserver reliability was measured with the intraclass correlation coefficient, which was very good, with a coefficient of 0.89 with a $95 \%$ confidence interval of $0.84-0.90$. The data were also analyzed regarding the appearance and fusion of the os terminale ossification center. The mean age at which the ossification center of the os terminale appeared was 47 months, with an SD of 12 months (Fig 3 ). The mean age at which the os terminale ossification center showed fusion was 8.6 years, with an SD of 1.1 years (Fig 4).

AJNR Am J Neuroradiol 38:2380-84 Dec 2017 www.ajnr.org 


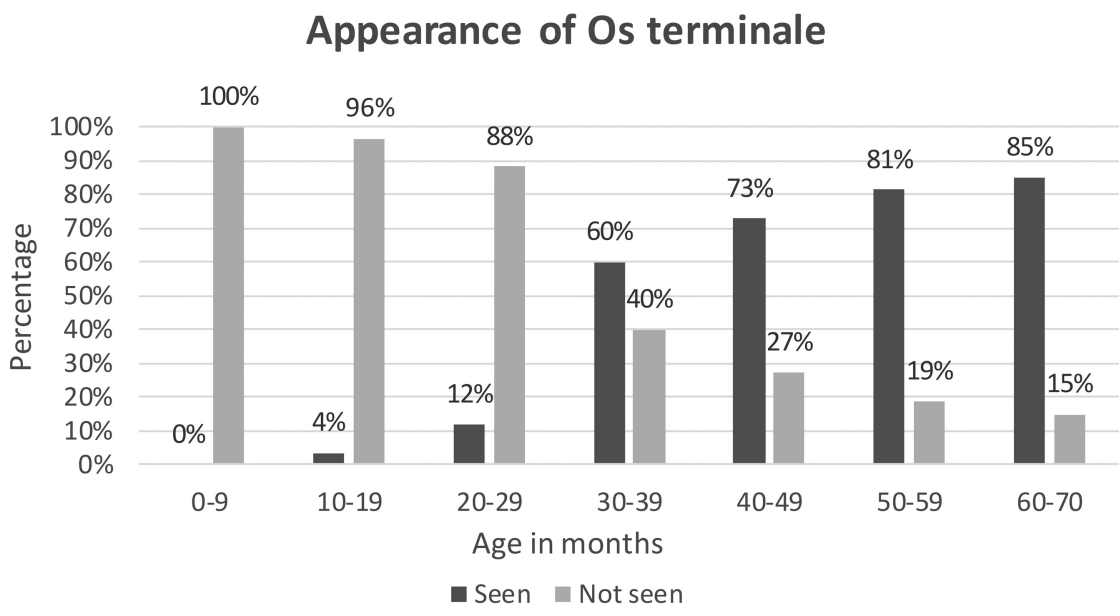

FIG 3. Bar chart for the appearance of the os terminale ossification center in children.

Fusion of os terminale

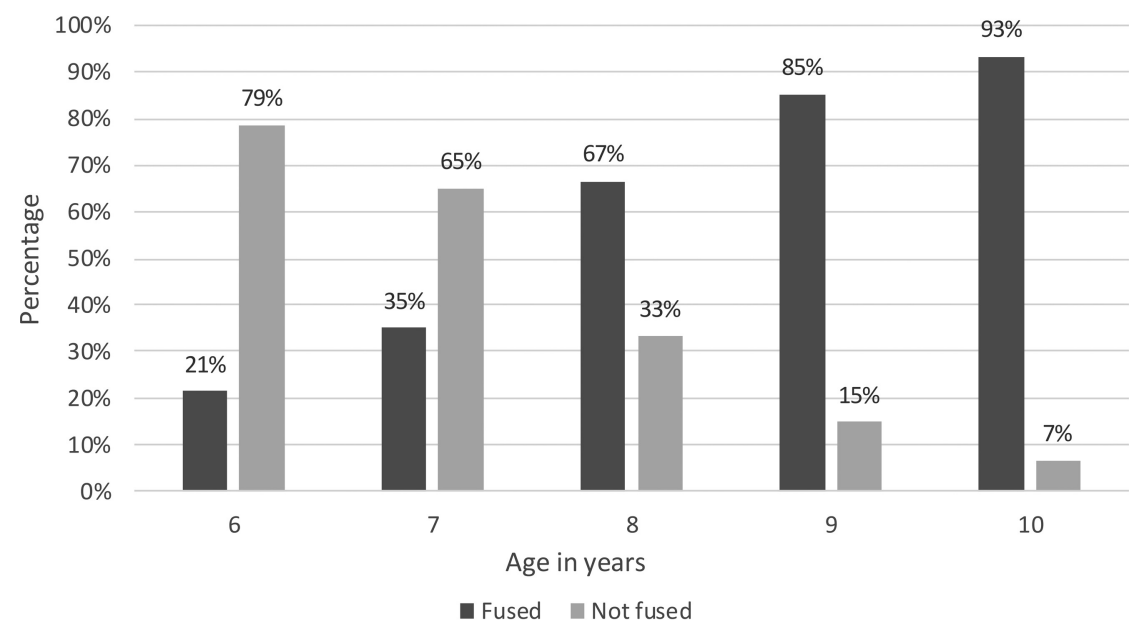

FIG 4. Bar chart for the fusion of the os terminale ossification center in children.

cipital sclerotomes form the clivus below the spheno-occipital synchondrosis (basiocciput). The third occipital sclerotome forms the exoccipital bone, which forms the jugular tubercle. The fourth occipital sclerotome (proatlas) divides into cranial and caudal halves, with the cranial half forming the tip of the clivus, occipital condyles, and the margin of foramen magnum. The lateral mass and superior portion of the posterior arch are formed by the caudal division of the proatlas (fourth occipital sclerotome), and the posterior and inferior portions of the arch are formed by the first spinal sclerotome. The anterior arch is formed by the hypocentrum of the first spinal sclerotome. The centrum of the second spinal sclerotome forms the body of the axis, and the neural arch forms the facets and posterior arch of the axis. The centrum of the first spinal sclerotome forms the odontoid process.

In a 17-mm embryo (Carnegie stages 18 and 19, 44-46 days after fertilization), the odontoid process is a dense mass of mesenchymal tissue located close to the future anterior foramen magnum. The chondrification of the odontoid starts from the base in stage 21 (51 days after fertilization). ${ }^{11,12}$ The odontoid ossification begins at the base from 2 ossification centers that fuse in the midline by the seventh gestational month. The terminal portion of odontoid arises from the proatlas (the fourth

\section{DISCUSSION}

The craniovertebral junction comprises the occiput, atlas, and axis with associated ligaments. These ligaments play an important role in the stability of the CVJ. The anterior atlanto-occipital membrane is the cranial extension of the anterior longitudinal ligament and extends superiorly to the clivus. The apical ligament extends from the dens to the clivus. The transverse band of the cruciform ligament is the main stabilizing ligament of atlantoaxial joint and passes behind the dens to attach to the lateral masses of the atlas. The ascending and descending bands of the cruciform ligament attach to the clivus and body of $\mathrm{C} 2$, respectively. The tectorial membrane is the cranial extension of the posterior longitudinal ligament and passes behind the cruciform ligament to attach to the clivus. The paired alar ligaments extend from the superolateral margins of the dens to the medial aspect of the occipital condyles. The posterior atlanto-occipital membrane is the cranial extension of the ligamentum flavum and extends from the anterior aspect of the posterior arch of the atlas to the posterior aspect of the foramen magnum. ${ }^{9,10}$

It is important to be aware of the embryology of the CVJ to understand the anatomy. The craniovertebral junction is formed from the 4 occipital and 2 upper spinal sclerotomes. First, 2 oc- occipital sclerotome). The most inferior portion of the axis body is formed by the second spinal sclerotome. ${ }^{13-15}$ The body of C2 fuses with the odontoid by 3-6 years of age. A secondary ossification center (os terminale) at the apex of the odontoid process appears between 3 and 6 years of age and usually fuses by 12 years. ${ }^{16,17}$ The cruciate and alar ligaments share the common mesenchymal origin in the tip of the primitive odontoid process. $^{12,18}$ The apical ligament is a functional vestige of the notochord and arises from either the notochord or its sheath. ${ }^{12,19,20}$

Craniovertebral junction injuries are unstable, potentially fatal injuries and should be diagnosed promptly on the initial imaging studies. The basion-dens interval is an important imaging parameter for CVJ injuries, described by Wholey et al in $1958 .^{21}$ Normal values of the basion-dens interval in the adult population have been well-described in the literature. In a study by Harris et $\mathrm{al}^{22}$ the basion-dens interval was $<12 \mathrm{~mm}$ in $95 \%$ of adult patients on lateral cervical spine radiographs.

However, BDI values on CT are different from those of radiographs due to better delineation of the anatomy. Gonzalez et $\mathrm{al}^{23}$ reported that a BDI of $>9 \mathrm{~mm}$ on CT is suggestive of injury to the craniovertebral junction. In a study by Rojas et al, ${ }^{24} \mathrm{BDI}$ values of 


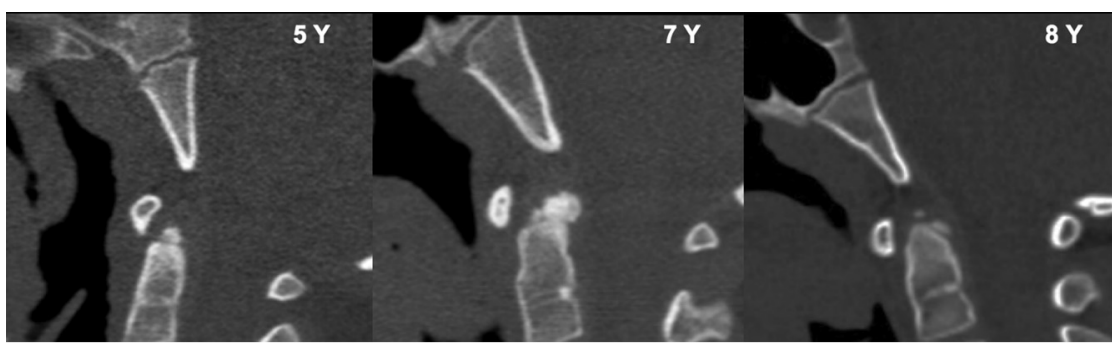

FIG 5. Sagittal CT cervical spine images in 3 children of different ages show the variable appearance of the os terminale.
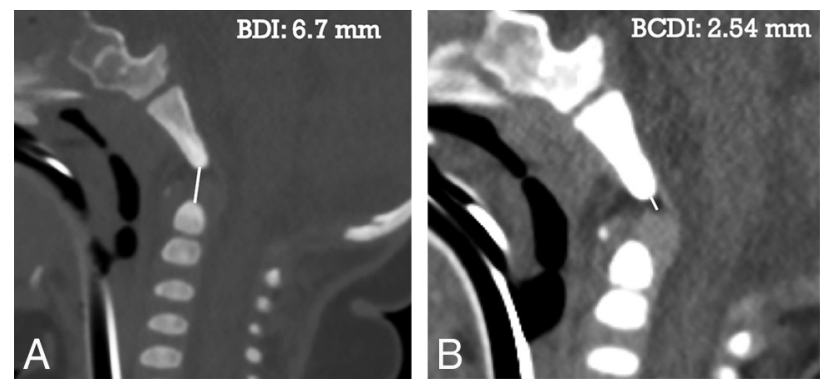

FIG 6. Comparison of $\mathrm{BDI}$ versus $\mathrm{BCDI}$ in a 6-month-old child. $A$, Sagittal CT cervical spine image in a bone window shows the BDI as 6.7 $\mathrm{mm}$. $B$, Sagittal CT cervical spine image in a soft-tissue window shows the BCDI as $2.54 \mathrm{~mm}$.

$<8.5 \mathrm{~mm}$ were seen in $95 \%$ of patients (of 200) on CT. Omercikoglu et $\mathrm{al}^{25}$ also reported a BDI of $8.5 \mathrm{~mm}$ as the optimal upper limit of normal on CT in their study of 499 patients.

The literature on the BDI in the pediatric population is very limited. Bulas et $\mathrm{al}^{26}$ mentioned $12.5 \mathrm{~mm}$ as an upper limit of normal on cervical spine radiographs in a study on 110 patients. Bertozzi et $\mathrm{al}^{27}$ studied the basion-dens interval in 117 healthy children and found that the normal maximum value of the BDI is $9.5 \mathrm{~mm}$ if the os terminale is ossified and $11.6 \mathrm{~mm}$ if it is not ossified. Vachhrajani et $\mathrm{al}^{28}$ reported $7.49 \mathrm{~mm}$ as the upper tolerance limit for the BDI in 42 pediatric patients. The basion-dens interval is highly variable in children due to the developing dens and the variable ossification of the os terminale (Fig 5).

Recognizing that an inherent problem with the BDI in the pediatric population is that it does not include cartilage in the measurement, Birchansky et $\mathrm{al}^{8}$ were the first group to devise a new imaging parameter utilizing sagittal CT soft tissue window reformats to measure the distance from the basion to the readily observed cartilaginous dens tip. In their study, this novel distance was coined as the "basion-cartilaginous dens interval" (BCDI). They measured the BCDI in 86 children between $0-24$ months of age and calculated the upper limit of normal to be $4.4 \mathrm{~mm} .^{8}$

Our results show that the BCDI varies with age, with the upper tolerance limit of $5.6 \mathrm{~mm}$ in children up to 6 years of age and 7.2 $\mathrm{mm}$ in children 6-10 years of age. Our results for the BCDI are smaller than those in prior studies that measured the BDI because the 2 measurements used different landmarks. The BCDI should serve as a substitute for the BDI in the pediatric population, especially in younger children in whom the dens is not completely formed because BCDI is measured from the clivus to the cartilaginous dens where ligaments attach. An example is shown in Fig 6 for comparing the BCDI versus BDI.

\section{CONCLUSIONS}

\section{REFERENCES} Medline Medline CrossRef Medline Medline CrossRef Medline
Some limitations of our study are due to its retrospective nature, such as selection bias; however, we tried to minimize this bias by prospectively selecting patients in the PACS from 2013 to 2016 after the careful application of exclusion criteria. The other limitation of this study is that we only looked at the BCDI values in the healthy pediatric population. We need to compare these data with data from patients with actual CVJ injury to validate these measurements.

The BDI is an important imaging parameter of a craniovertebral junction injury in adults on cervical spine CT. However, its use in pediatric patients is limited due to the variable appearance of the developing os terminale. The BCDI is a recently described novel imaging parameter to assess the CVJ integrity in children that includes nonossified cartilage in the measurement. We believe that the BCDI may be a helpful imaging marker of CVJ injury in children; however, more studies are needed to validate this claim.

1. Dietrich AM, Ginn-Pease ME, Bartkowski HM, et al. Pediatric cervical spine fractures: predominantly subtle presentation. J Pediatr Surg 1991;26:995-99; discussion 99-100 CrossRef Medline

2. Kokoska ER, Keller MS, Rallo MC, et al. Characteristics of pediatric cervical spine injuries. J Pediatr Surg 2001;36:100-05 CrossRef

3. Patel JC, Tepas JJ 3rd, Mollitt DL, et al. Pediatric cervical spine injuries: defining the disease. J Pediatr Surg 2001;36:373-76 CrossRef

4. Hamilton MG, Myles ST. Pediatric spinal injury: review of $\mathbf{1 7 4}$ hospital admissions. J Neurosurg 1992;77:700-04 CrossRef Medline

5. Hadley MN, Zabramski JM, Browner CM, et al. Pediatric spinal trauma: review of 122 cases of spinal cord and vertebral column injuries. J Neurosurg 1988;68:18-24 CrossRef Medline

6. Junewick JJ. Pediatric craniocervical junction injuries. AJR Am J Roentgenol 2011;196:1003-10 CrossRef Medline

7. Goldstein HE, Anderson RC. Classification and management of pediatric craniocervical injuries. Neurosurg Clin N Am 2017;28:73-90

8. Birchansky S, Syed H, Jea A, et al. Pediatric craniocervical metrics revisited: establishing landmark CT measurements of basion-cartilaginous dens interval (BCDI) in infants using soft tissue window. In: Proceeding of the American Society of Head and Neck Radiology 50th Annual Meeting, Washington, DC. September 7-11, 2016

9. Junewick JJ, Meesa IR, Luttenton CR, et al. Occult injury of the pediatric craniocervical junction. Emerg Radiol 2009;16:483-88 CrossRef

10. Grabb BC, Frye TA, Hedlund GL, et al. MRI diagnosis of suspected atlanto-occipital dissociation in childhood. Pediatr Radiol 1999;29: 275-81 CrossRef Medline

11. O'Rahilly R, Müller F. Developmental stages in human embryos: revised and new measurements. Cells Tissues Organs 2010;192:73-84

12. Hita-Contreras F, Roda O, Martinez-Amat A, et al. Embryonic and early fetal period development and morphogenesis of human craniovertebral junction. Clin Anat 2014;27:337-45 CrossRef Medline

13. Menezes AH. Craniocervical developmental anatomy and its implications. Childs Nerv Syst 2008;24:1109-22 CrossRef Medline 
14. Raybaud C. Anatomy and development of the craniovertebral junction. Neurol Sci 2011;32(suppl 3):S267-70 CrossRef Medline

15. Pang D, Thompson DN. Embryology and bony malformations of the craniovertebral junction. Childs Nerv Syst 2011;27:523-64 CrossRef Medline

16. Akobo S, Rizk E, Loukas M, et al. The odontoid process: a comprehensive review of its anatomy, embryology, and variations. Childs Nerv Syst 2015;31:2025-34 CrossRef Medline

17. Lustrin ES, Karakas SP, Ortiz AO, et al. Pediatric cervical spine: normal anatomy, variants, and trauma. Radiographics 2003;23:539-60 CrossRef Medline

18. Ludwig KS. Early development of atlas and occipital vertebra in man [in German]. Acta Anat (Basel) 1957;30:444-61 CrossRef Medline

19. O’Rahilly R, Müller F, Meyer DB. The human vertebral column at the end of the embryonic period proper, 2: the occipitocervical region. J Anat 1983;136(pt 1):181-95 Medline

20. Abe $\mathrm{H}$, Ishizawa $\mathrm{A}$, Cho $\mathrm{KH}$, et al. Fetal development of the transverse atlantis and alar ligaments at the craniovertebral junction. Clin Anat 2012;25:714-21 CrossRef Medline

21. Wholey MH, Bruwer AJ, Baker HL Jr. The lateral roentgenogram of the neck; with comments on the atlanto-odontoid-basion relationship. Radiology 1958;7:350-56 CrossRef Medline
22. Harris JH Jr, Carson GC, Wagner LK. Radiologic diagnosis of traumatic occipitovertebral dissociation, 1: normal occipitovertebral relationships on lateral radiographs of supine subjects. AJR Am J Roentgenol 1994;162:881-86 CrossRef Medline

23. Gonzalez LF, Fiorella D, Crawford NR, et al. Vertical atlantoaxial distraction injuries: radiological criteria and clinical implications. J Neurosurg Spine 2004;1:273-80 CrossRef Medline

24. Rojas CA, Bertozzi JC, Martinez CR, et al. Reassessment of the craniocervical junction: normal values on CT. AJNR Am J Neuroradiol 2007;28:1819-23 CrossRef Medline

25. Omercikoglu S, Altunbas E, Akoglu H, et al. Normal values of cervical vertebral measurements according to age and sex in CT. Am J Emerg Med 2017;35:383-90 CrossRef Medline

26. Bulas DI, Fitz CR, Johnson DL. Traumatic atlanto-occipital dislocation in children. Radiology 1993;188:1555-58 CrossRef Medline

27. Bertozzi JC, Rojas CA, Martinez CR. Evaluation of the pediatric craniocervical junction on MDCT. AJR Am J Roentgenol 2009;192: 26-31 CrossRef Medline

28. Vachhrajani S, Sen AN, Satyan K, et al. Estimation of normal computed tomography measurements for the upper cervical spine in the pediatric age group. J Neurosurg Pediatr 2014;14: 425-33 CrossRef Medline 